\title{
Predictors of Young People's Career Intentions as Islamic Bankers
}

\author{
Hanudin Amin \\ Universiti Malaysia Sabah, Malaysia \\ Corresponding email: hanudin@ums.edu.my
}

Received: June $7^{\text {th }}, 2020$ Revised: June $30^{\text {th }}, 2020$ Accepted: July $20^{\text {th }}, 2020$

\begin{abstract}
Understanding the willingness of university students pursuing their career as Islamic bankers has proven to be one of the most challenging research topics in the Islamic banking field. This study examines the factors affecting the career intentions as Islamic bankers among university students in Malaysia. Drawing upon Decomposed Theory of Planned Behavior (DTPB), this study examined the factors determining the students' willingness to become Islamic bankers as their future job. Our analysis is based on the 350 respondents involved. Results obtained show that all factors are examined were instrumental in determining the career intentions as Islamic bankers. Our findings should be interpreted with caution. We identified two limitations, first is on the use of the university students as proxies and second our data which was confined to Islamic finance program whilst neglecting other students from business and finance disciplines. The results help improve the role of bank managers to provide proper packages of training to improve the students' confident to become future Islamic bankers. Besides, this study extends the DTPB's applicability to include career intentions as Islamic bankers in a Malaysia context.
\end{abstract}

Keywords: Student, Islamic Banker, DTPB, Graduates, Malaysia.

JEL Classification : A22; C83; J24; P36

@ IJIEF 2020 published by Universitas Muhammadiyah Yogyakarta, Indonesia All rights reserved

DOI:

https://doi.org/10.18196/ijief.3225

\section{Web:}

https://journal.umy.ac.id/index.php/ijief/article/view/8970

Citation:

Amin, H. (2020) Predictors of young people's career intentions as Islamic bankers. International Journal of Islamic Economics and Finance (IJIEF), 3(2), 143-170. DOI: https://doi.org/10.18196/ijief.3225 
Amin | Predictors of Young People's Career Intentions as Islamic Bankers

\section{Introduction}

\subsection{Background}

Owing to the uncertain economic future of Islamic banking system drawn from the stern competition and public fallacy, Islamic banks are under increasing pressure not only in retaining their existing customers but also attracting the new ones. Bank customers have expectations concerning Islamic banking products that may be based on, firstly, financial benefits offered, secondly, satisfaction with the patronization with Islamic banks and lastly their satisfaction to deal with bankers who managed their queries effectively. Of these, reliable bankers are the key to gaining competitive advantage to build profitable long-term customer relationships, which contributes to greater sales volumes, secured repeat sales, positive word-ofmouth and importantly customer loyalty. Hiring the right person for the right job is challenging today for Islamic banks. Job seekers have options whether they want to end up with the banking industry or other industries, relatively based on their discretion and interest. The same case also goes to students at universities majoring banking and finance who have such discretion but somewhat are confused to determine their right career pathway due to lack of exposure and mixed opinions from diverse parties that leave them hanging and helpless.

Consequently, many become teachers and at their best they become entrepreneurs. Such a decision also leads to brain drain to the Islamic banking industry and also among themselves as they could not apply the theories that have been learnt at the university to practice. Similarly, they force themselves to learn a new discipline to secure their current jobs - at the expense of their knowledge extensions in Islamic banking. According to Bank Negara Malaysia (2011), the Islamic banking industry requires a pool of skilled talent that can drive the development of the Islamic banking industry. It is also asserted that the industry needs about 200,000 employees to meet the demand of well-educated employees in high growth and niche areas of the industry. Following ICD Thomson Reuters (2019), Malaysia is ranked first in the world with an index score of 131.86, followed by Bahrain (74.25) and United Arab Emirates (71.1) inter alia. In the South-East Asia countries, Malaysia has the highest score for Islamic Finance Development Indicator (IFDI) (131.86), followed by Brunei (50.45) and Indonesia (49.96), to mention some. If graduates are not tapping on this opportunity, the national agenda to be an international hub for Islamic finance could be difficult to be attained or else other countries will lead the way.

Current research on career choice, however, offers little guidance on career intentions as Islamic bankers. Given several growing studies across different 
Amin | Predictors of Young People's Career Intentions as Islamic Bankers

disciplines namely accounting (Law, 2010) and property management (Ayodele, 2019), support for the antecedents determining young intellectuals' willingness to become Islamic bankers remains equivocal. Moreover, there is a relative paucity of knowledge about the specific topic of career pathways as bankers and factors determining their likelihood are relatively fallen short. An interesting study by Mohd Zain et al. (2010) in Malaysia describes entrepreneurship intention among Malaysian business students. This study employs undergraduate students as samples to determine their career intentions to become entrepreneurs in the future. Family influences, academic performance and attended entrepreneurship courses, were jointly determined the intention. Equally, these studies have paid little attention to firstly, Islamic bankers as the research context and secondly the contributing factors determining the Islamic banker careers which warrant further empirical investigations to close the gap.

We identify three research gaps found in the extant literature but are not limited to: 1) Prior studies have paid limited attention to career intentions among young people to become Islamic bankers in the future (Mohd Zain et al., 2010, Law, 2010); 2) Efforts in extending the application of the DTPB to our present context are somewhat limited and to our knowledge, it is inconclusive (Md Husin \& Ab Rahman, 2016); and 3) Battery items developed to gauge career intentions from the context of young people are not properly developed in the extant pieces of literature (Law, 2010; Ayodele, 2019). The current study provides adjustment to the items to contribute to the body of knowledge in the area of Islamic banking employment.

\subsection{Objective}

In light with the context of the present study, the banks need to identify what factors young intellectuals consider to be the most important when opting to become Islamic bankers in the future. Hence, this study uses Decomposed Theory of Planned Behavior (DTPB) developed by Taylor and Todd (1995) as a baseline theory to identify potential key attributes and investigates the relationships between those attributes developed and young intellectuals' willingness to become future Islamic bankers, at least.

The rest of the paper is organised as follows. In Section 2, details of the literature review and hypotheses development are given. In Section 3, details of the methodology that covers data, model development and method are presented. Section 4 provides detail results on the measurement model, structural model and analysis whilst in Section 5, research implications are interpreted. Section 6 concludes the study. 
Amin | Predictors of Young People's Career Intentions as Islamic Bankers

\section{Literature Review and Hypotheses Development}

\subsection{Background Theory}

This study considers the DTPB as a baseline theory to explain the contributing factors determining young intellectuals' willingness to pursue a career as Islamic bankers. The DTPB was based on the Theory of Planned Behavior (TPB) that received extensions proposed by Taylor and Todd (1995) to enhance the theoretical contributions that can be drawn from the TPB. These authors decomposed the attitudinal belief, normative belief and control belief into several dimensional constructs to provide higher descriptive power and a more accurate understanding of the factors influencing behavioral formation. Through the decomposition, two advantages are documented but are not confined to these descriptions. First, the relationship between belief and the factors influencing intentions would become clearer and easy to be understood. Second, the act of decomposition can provide a stable set of beliefs, which can be applied across a variety of contexts.

Our decisions to select the DTPB are due to two reasons. First, the DTPB considers wider factors relevant to understand the individuals' formation of willingness to pursue Islamic bankers. The factors embedded in the DTPB were decomposed into more manageable specific factors that contribute to the performance of the first level factor. The second reason is driven by the fact that the DTPB is expected to provide more accurate and precise empirical findings on the development of behavioral intention in the area under contemplation - hence closing the research gaps existed in the literature.

In our work, the DTPB is modified to better reflect the research context in which a new discipline of Islamic banking comes into play. Besides, the modification also includes new variables that can extend the applicability of the theory into the present context. The decomposition acts are extended to attitude, subjective norm and perceived behavioral control within the realm of Islamic bankers. Furthermore, attitude is influenced by religiosity index and career reputation. Subjective norm is determined by descriptive and injunctive norms. Perceived behavioral control is influenced by self-efficacy. Facilitating condition is also included in which supports from Islamic banks to equip students with necessary information can accelerate their intentions to become future Islamic bankers for the Islamic banking industry.

International Journal of Islamic Economics and Finance (IJIEF), 3(2), 143-170|146 
Amin | Predictors of Young People's Career Intentions as Islamic Bankers

\subsection{Previous Studies}

\subsubsection{Attitude}

Attitude is defined as one's belief that being an Islamic banker is whether favorable or opposite, and its importance has earned empirical support from various disciplines of job seeker intentions (Lin, 2010; Van Hooft and De Jong, 2009). It is expected in other contexts that one's good attitude can be translated in the form of significant outcome and it is directed for the formation of his willingness to pursue a career as Islamic bankers. A work by Van Hooft and De Jong (2009) examined job search intention, and later job search behavior. This study reported a significant effect brought job search attitude on the job search intention, in turn, affected job search behavior. Additionally, beliefs related to viewing temporary employment as a means to provide a sense of freedom and secure a good work-life balance. Likewise, Lin (2010) found a significant relationship between attitude and job seeker intentions. The result obtained was in such way because job seekers perceive a job search website to have a user-friendly web design and to be easy to navigate, their attitudes are likely to be positive. In another context, Khapova et al. (2007) argued that behaviors that were believed to have desirable outcomes were favored and vice versa, implying that those professionals who had a favorable disposition towards career will more likely to perform favorable behavior. These studies jointly lead us to the following hypothesis:

H1: Attitude is significantly related to the willingness to pursue a career as Islamic bankers

\subsubsection{Religiosity}

Laura et al. (2012) investigated spirituality in undergraduate social work career choice. The study found out that more than 80 per cent of students considered their spirituality to be influential in their career choice. Unlike Laura et al. (2012), Abu Bakar et al. (2016) studied religiosity as a source of influence on work engagement and found a positive impact of religiosity on several human resources and organizational outcomes. However, few studies treat religious belief as a job or personal resource from a human resource management perspective. Importantly, the study reported that religiosity was essential in determining work engagement. Further, Wibowo (2017) examined the relationship between religiosity and entrepreneurial intention in Indonesia and found it was essential in the formation of the personal attitude to carry out an entrepreneurial activity in systematic manners. Unlike Laura et al. (2012) and Abu Bakar et al. (2016), Wibowo (2017) discovered that entrepreneurial intentions were statistically significant 
Amin | Predictors of Young People's Career Intentions as Islamic Bankers

between a religious group and non-religious group. In other words, the religious group tends to have more conducive perception towards the entrepreneur as a profession. Based on their findings, $\mathrm{H} 2$ is postulated as:

$\mathrm{H}_{2}$ : Religiosity is significantly related to the attitude towards the willingness to pursue a career as Islamic bankers

\subsubsection{Career Reputation}

An earlier work by Felton et al. (1994) examined factors influencing the business student's choice of a career in chartered accountancy. Evidently, certified accounting students appear to place more emphasis on good long term earnings and promising job market opportunities. Those who enrolled accounting perceived it as benefit exceeded cost whilst those who unrolled it perceived that the costs exceeded benefits. This work earned extensions. For instance, a study by Ahmed et al. (1997) examined factors affecting accounting students' career choice in New Zealand. The results indicate that potentially certified accountants see that the benefits of becoming professional accountants are greater than the associated costs. This finding is consistent with Turban et al.'s (1998) study who found out that organization reputation positively influenced perceptions of recruiter behaviors and job and organizational attributes. Unlike Sugahara and Boland (2006), Sugahara and Boland (2006) examined perceptions of the certified public accountants by accounting and non-accounting students in Japan. Evidently, career prospects in the majority determine job selection. Good advancement opportunities were statistically significant between accounting students and non-accounting students. Hence, $\mathrm{H} 3$ is proposed as:

$\mathrm{H}_{3}$ : Career reputation is significantly related to the attitude towards the willingness to pursue a career as Islamic bankers

\subsubsection{Subjective Norm}

Following Ajzen (1991), people expectations were important to impact one's behavior whether to perform or not to perform the behavior under contemplation. Still Ajzen (2002), social pressure mainly what people believe can influence the viewpoint concerning the behavior and so do the current context. In another study, Khapova et al. (2007) found a significant relationship between subjective norm and career behavior, implying one's decision is related to what shared by others on some particular issues. It is a matter of fact, some individuals place greater importance on what others believe and comply than that of themselves out of inconsistency in their confidence but improved when the second opinion comes into play. 
Amin | Predictors of Young People's Career Intentions as Islamic Bankers

Likewise, Lin (2010) found a significant relationship between subjective norm and job seeker intentions. The result obtained was so because job seekers perceive people support as of today are encouraging and optimistic to those job seekers for the improved status of life. Therefore, the more individuals are under social pressure to pursue their career, the more likely they to have stronger intentions toward career advancement. Given these assertions, $\mathrm{H} 4$ is hypothesized as:

$\mathrm{H}_{4}$ : Subjective norm is significantly related to the willingness to pursue a career as Islamic bankers.

\subsubsection{Injunctive Norm}

Taylor and Todd (1995) found subjective norm was related to the injunctive norm in explaining certain behavior. Following Aronson et al. (2010), injunctive norms are people's perceptions of what behaviors are approved of or disapproved of by others. In other words, it explicates about the approval of certain behavior as if one gets into it out of a green light offered by others in his social circle. Prior studies have indicated that injunctive norm affects individuals' beliefs about the people influence in their decision making (Cialdini, 2007; Smith and Louis, 2008). Consistent with previous studies, this study treats injunctive norm on subjective norm belief. Indeed, injunctive norms provide individuals with important information about what the relevant peer group believes should or ought to be done concerning particular social behavior. Besides, the norms send messages regarding the implied social sanctions that may arise from not conforming to the ideals of a relevant peer group (Cialdini, 2007). Thus, in the context of Islamic bankers recruitment services, university students' behavior can be shaped by the information they received about what other students at their university are indicating should be done. Our assertion is supported by Smith and Louis (2008) who believed that knowledge dissemination of others doing can influence others doing too. Hence, the following hypothesis is proposed:

$\mathrm{H}_{5}$ : Injunctive norm is significantly related to the subjective norm towards the willingness to pursue a career as Islamic bankers

\subsubsection{Descriptive Norm}

The term descriptive norms may imply the frequency with which an individual's peer group participates in behavior or endorses a particular belief or attitude can significantly predict behavioral intention (Cialdini, 2007; Smith and Louis, 2008). In other words, it is referred to one's belief about whether

International Journal of Islamic Economics and Finance (IJIEF), 3(2), 143-170|149 
Amin | Predictors of Young People’s Career Intentions as Islamic Bankers

most individuals important to him will pursue a career as Islamic bankers in the future. In more detail, a descriptive norm regarding career intentions as Islamic bankers involves understanding the frequency with which the peer group participate in the discussion of the issue concerned and being pursuing career intentions. For instance, my close friends will pursue a career as Islamic bankers in the future or another example is my siblings will pursue a career as Islamic bankers in the future (See Taylor and Todd, 1995). Unlike the injunctive norm, descriptive norm explains a student's peer group believes that other students should become as Islamic bankers in the future. The manipulation of public perception of the descriptive norm has been shown to influence the frequency and intensity with which peer groups endorse particular behaviors (Lawson, 2016). So do career intentions as Islamic bankers. Hence, $\mathrm{H}_{6}$ is hypothesized as:

$\mathrm{H}_{6}$ : Descriptive norm is significantly related to the subjective norm towards the willingness to pursue a career as Islamic bankers

\subsubsection{Perceived Behavioral Control}

Following Ajzen (1991), perceived behavioral control is defined as perceived control over the performance of behavior and suggests it is a concept of selfefficacy. Mathieson's (1991) definition of perceived behavioral control is the individual's perception of his or her control over the performance of the behavior. Mathieson (1991) demonstrated that behavioral control influences the intention to use a piece of information. A positive relationship between perceived behavioral control and intentions is also found in Taylor and Todd (1995) study, which examines users in a computer resources center. Jointly, these studies provide departure. In our study, however, perceived behavioral control was decomposed into self-efficacy and facilitating condition. Self-efficacy is a cognitive appraisal or judgment of future performance capabilities and must be measured against some type of behavior. It refers to "people's judgments of their capabilities to organize and execute courses of action required to attain designated types of performances" (Bandura, 1986). A study by Lin (2010) confirmed a significant effect of perceived behavioral control on career intentions. The behavior is shaped when individuals have beliefs in that the doing is facilitated if there are no or limited constraints found in performing a behavior. Therefore, we postulate:

$\mathrm{H}_{7}$ : Perceived behavioral control is significantly related to the willingness to pursue a career as Islamic bankers

International Journal of Islamic Economics and Finance (IJIEF), 3(2), 143-170|150 
Amin | Predictors of Young People's Career Intentions as Islamic Bankers

\subsubsection{Career Self-Efficacy}

Prior studies have documented the importance of self- efficacy as an independent variable, where perceived behavioral control is brought into play. A study by Md Husin and Ab Rahman (2016) provides an interesting result pertinent to the effect of self-efficacy in which it was discovered that self-efficacy was significantly related to perceived behavioral control. Likewise, this result is expected as one's skill and capability to do certain behavior are essential in the formation of a behavior (Bandura, 1986). This outcome earlier was supported by another interesting study by Zolait (2010). Clearly, Zolait (2010) confirmed the significant relationship self- efficacy and perceived behavioral control, in the context of internet banking and we expect to extend its applicability to the career intention. These two studies are benefited from an interesting work by Shih and Fang (2004) in which they found that self-efficacy was essential in influencing perceived behavioral control. Hence, a person who is skillful and knowledgeable are expected to perform a behavior better than other peers. Despite its importance, there exists no study examining the importance of this variable in the context of career intentions as Islamic bankers out of differences in research scope and paradigm of inquiry. Based on this assertion, $\mathrm{H}_{8}$ is thus hypothesized as:

$\mathrm{H}_{8}$ : Career self-efficacy is significantly related to the perceived behavioral control towards the willingness to pursue a career as Islamic bankers

\subsubsection{Facilitating Condition}

Zolait (2010) proposed a relationship between facilitating condition and perceived behavioral control. The result obtained, however, was insignificant - implying resources (i.e. information and support) needed are somehow incomplete and unreachable and for that issues of controllability and ability are not influencing one's decision. However, the relationship found was insignificant - implying it is not a factor. However, a study by Md Husin and Ab Rahman (2016) reported different outcome in which facilitating condition is essential for the formation of behavior. In general, resources like time, money or even opportunities are known as influencing factors on perceived behavioral control (Md Husin and Ab Rahman, 2016; Ajzen, 1991). Given its flexibility, Rana et al. (2015) discovered the significant effect of facilitating condition on behavioral intention, mainly in the context of e-government. Users who had a capacity tended to undertake an effort to perform the behavior. The findings of these authors had been following the outcomes of the previous studies (Taylor and Todd, 1995). The finding here is in tandem with a work of Teo et al. (2008), who asserted that facilitating conditions are environmental factors that influence individuals' willingness to undertake 
Amin | Predictors of Young People's Career Intentions as Islamic Bankers

certain types of tasks. When an individual believes that they have more resources, their perceptions of control are relatively high and hence their behavioral intention can increase. Thus, $\mathrm{H}_{9}$ is postulated as:

$\mathrm{H}_{9}$ : Facilitating condition is significantly related to the perceived behavioral control towards the willingness to pursue a career as Islamic bankers

\section{Methodology}

\subsection{Data}

Subjects of this study were final year students at a public university in East Malaysia. Employing judgmental sampling for data collection, two criteria were used as follows - First, the students chosen have considered becoming future Islamic bankers once they complete their studies, and second, the students chosen are well-exposed and trained by Islamic finance scholars for adulthood and enhanced learning experiences. As for data collection, a total of 400 questionnaires are provided to elicit responses from the respondents chosen. The data collection was conducted from 1st December 2019 until 31st January 2020 to generate variations in respondents' responses. Of these, we managed to get 350 usable questionnaires that qualify them for further analysis of the data collected. Table 1 depicts our profiles of respondents.

Our battery items were adapted from selected previous studies. Three items for attitude were adapted from Taylor and Todd (1995). One item for career reputation was adapted from Felton et al. (1994) and two items were adapted from Sugahara and Boland (2006). Three items for religiosity were adapted from Abu Bakar et al. (2016). Three items each for subjective norm, injunctive norm and descriptive norm were adapted from Taylor and Todd (1995). Moreover, three items for perceived behavioral control were adapted from Taylor and Todd (1995). Three items for self-efficacy were adapted from Shih and Fang (2004). In terms of facilitating condition, two items were adapted from Taylor and Todd (1995) and one from Shih and Fang (2004). Three items for willingness were adapted from Shih and Fang (2004). For each battery item, a Likert-type scale of 1-5 was used. Prior to the actual fieldwork, we have conducted a pilot test to identify any ambiguity associated with the battery items and based on our finding, the changes are directed only in terms of the layout and vocabulary for clarity.

International Journal of Islamic Economics and Finance (IJIEF), 3(2), 143-170|152 
Amin | Predictors of Young People’s Career Intentions as Islamic Bankers

Table 1. Demographic Details

\begin{tabular}{llcc}
\hline Demographic & Detail & Sample & Percentage \\
\hline Gender & Female & 236 & $67.40 \%$ \\
& Male & 114 & $32.60 \%$ \\
Age & $<20$ & 12 & $3.40 \%$ \\
& $21-30$ & 336 & $96.00 \%$ \\
\multirow{2}{*}{ Ethnic } & $>31$ & 2 & $0.60 \%$ \\
& Malay & 240 & $68.60 \%$ \\
& Aboriginal Sabahan & 94 & $26.90 \%$ \\
& Aboriginal Sarawakian & 16 & $4.60 \%$ \\
\hline
\end{tabular}

Source: Author's analyzed data

\subsection{Model Development}

Our study's model is based on the DTPB, which is revised to reflect our context, that is career intentions as Islamic bankers. All items are revised to measure final year students' willingness to become Islamic bankers. The model has a single main dependent variable, that is career intentions. This dependent variable is hypothesized to be influenced by attitude, perceived behavioural control and subjective norm. Each variable is composed of subvariables to reflect the DTPB. The hypothesized relationships are established based on our literature analyses (Taylor and Todd, 1995; Md Husin and Ab Rahman, 2016). Given this description, Figure 1 is presented as follows:

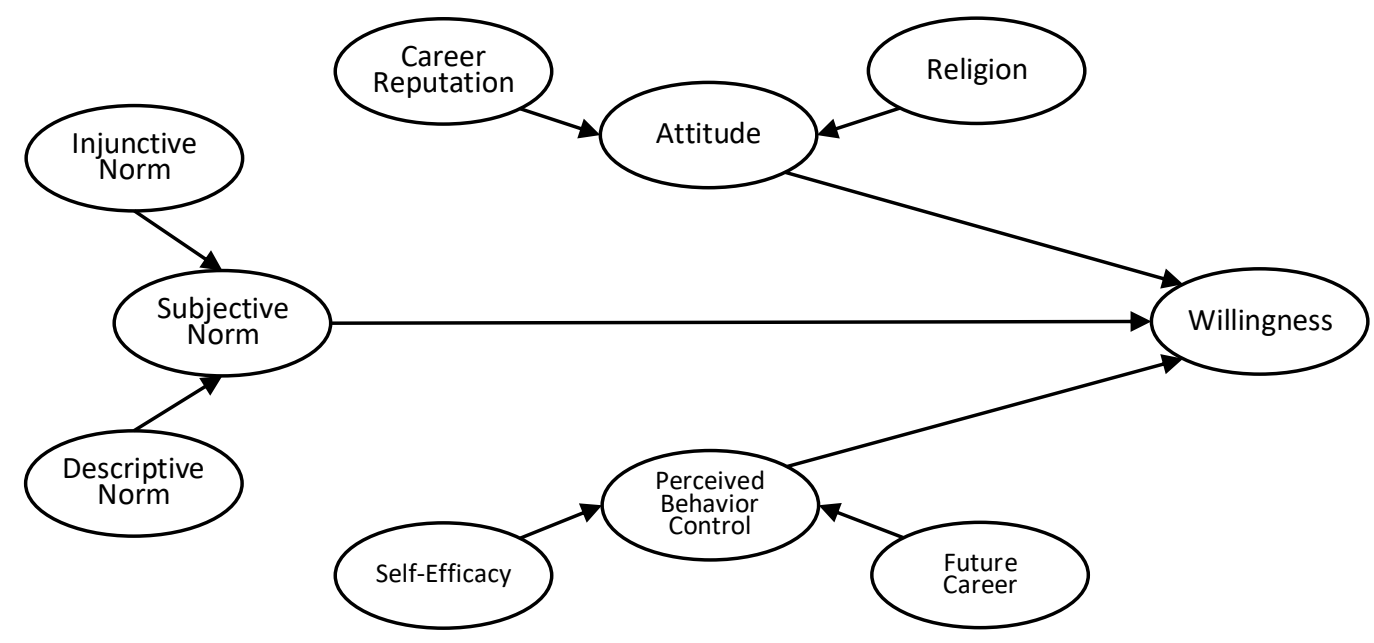

Figure 1. Research Model

International Journal of Islamic Economics and Finance (IJIEF), 3(2), 143-170|153 
Amin | Predictors of Young People’s Career Intentions as Islamic Bankers

\subsection{Method}

Partial Least Squares-Structural Equation Modeling (PLS-SEM) was employed to examine our research hypotheses using a software developed by Ringle et al. (2005) namely SmartPLS2.0 M3. PLS-SEM is both appropriate to be applied to a sample size of less than 250 and a sample size of more than 250 (Hair et al., 2016). It is the softer model of SEM, which relaxes the distributional requirement. PLS-SEM is a non-parametric method, which is not relied on any distribution of the sample under investigation. It is very robust model estimations with data that have normal as well as extremely non-normal distributional properties (Reinartz et al., 2009). This is proven by a study by Lee and Kozar (2008) work in which their sample size of 312 documented robust and significant finding - PLS-SEM produces improved estimates for the hypotheses developed and so do in the case of the present study. Because of this, PLS-SEM is appropriate. Besides, PLS-SEM is easier to use or in other words, it provides simultaneous results for factor analysis, discriminant validity and structural analysis, where a graphic representation comes into play.

\section{Results}

\subsection{Measurement Model}

This study employs a two-stage approach to analyze data. First, the approach considers the measurement model that can take some particular steps for data purification and the avoidance of cross-loadings in factor analysis. The analyses included are factor loadings, reliability test and composite reliability, to mention some. If all items meet these analyses, all of them will be retained for the second stage. In the second stage, a structural analysis displays the relationship between the variables tested and the criterion variable. This stage is useful to examine whether the null hypotheses need to be rejected or not, and later inferences can be documented accordingly.

Table 2 presents the results obtained from factor analysis. All items were statistically significant in representing the variables that they supposed to measure with. All items were loaded beyond the recommended value of 0.707 and for that, the discriminant validity is not an issue. 
Amin | Predictors of Young People's Career Intentions as Islamic Bankers

Table 2. Factor Analysis

\begin{tabular}{|c|c|c|c|c|c|c|c|}
\hline Factor & Item & Source & Code & $\mathrm{FL}$ & AVE & CR & $\mathrm{CA}$ \\
\hline ATT & $\begin{array}{l}\text { Becoming an Islamic banker } \\
\text { is a good idea } \\
\text { Becoming an Islamic banker } \\
\text { is something positive } \\
\text { Becoming an Islamic banker } \\
\text { is beneficial }\end{array}$ & $\begin{array}{l}\text { Taylor and } \\
\text { Todd (1995) } \\
\text { Taylor and } \\
\text { Todd (1995) } \\
\text { Taylor and } \\
\text { Todd (1995) }\end{array}$ & ATT2 & $\begin{array}{l}0.798 \\
0.795\end{array}$ & 0.653 & 0.850 & 0.735 \\
\hline CR & $\begin{array}{l}\text { Pursuing a career as an } \\
\text { Islamic banker has a good } \\
\text { long term earning } \\
\text { Being as a future Islamic } \\
\text { banker has excellent } \\
\text { prospects } \\
\text { Being as a future Islamic } \\
\text { banker has high social } \\
\text { prestige }\end{array}$ & $\begin{array}{l}\text { Felton et al. } \\
(1994) \\
\text { Sugahara and } \\
\text { Boland (2006) } \\
\text { Sugahara and } \\
\text { Boland (2006) }\end{array}$ & CR1 & 0.819 & 0.688 & 0.869 & 0.776 \\
\hline DN & $\begin{array}{l}\text { My friends will pursue their } \\
\text { future career as Islamic } \\
\text { bankers } \\
\text { My siblings will pursue their } \\
\text { future career as Islamic } \\
\text { bankers } \\
\text { Most people who are } \\
\text { significant to me will pursue } \\
\text { their future career as Islamic } \\
\text { bankers }\end{array}$ & $\begin{array}{l}\text { Taylor and } \\
\text { Todd (1995) } \\
\text { Taylor and } \\
\text { Todd (1995) } \\
\text { Taylor and } \\
\text { Todd (1995) }\end{array}$ & DN1 & 0.878 & 0.700 & 0.875 & 0.787 \\
\hline SN & $\begin{array}{l}\text { The people who influence } \\
\text { my decisions would think } \\
\text { that I should pursue my } \\
\text { future career as an Islamic } \\
\text { banker } \\
\text { The people who influence } \\
\text { my decisions would think } \\
\text { that I should consider my } \\
\text { future career as an Islamic } \\
\text { banker } \\
\text { The people who influence } \\
\text { my decisions would think } \\
\text { that I should define my } \\
\text { future career as an Islamic } \\
\text { banker }\end{array}$ & $\begin{array}{l}\text { Taylor and } \\
\text { Todd (1995) }\end{array}$ & SN2 & 0.846 & 0.747 & 0.898 & 0.832 \\
\hline IN & $\begin{array}{l}\text { My parents will think I } \\
\text { should pursue my future } \\
\text { career as an Islamic banker } \\
\text { My siblings will think I should } \\
\text { pursue my future career as } \\
\text { an Islamic banker }\end{array}$ & $\begin{array}{l}\text { Taylor and } \\
\text { Todd (1995) } \\
\text { Taylor and } \\
\text { Todd (1995) }\end{array}$ & IN1 & 0.906 & 0.759 & 0.904 & 0.845 \\
\hline
\end{tabular}


Amin | Predictors of Young People’s Career Intentions as Islamic Bankers

\begin{tabular}{|c|c|c|c|c|c|c|c|}
\hline & $\begin{array}{l}\text { My friends will think I should } \\
\text { pursue my future career as } \\
\text { an Islamic banker }\end{array}$ & $\begin{array}{l}\text { Taylor and } \\
\text { Todd (1995) }\end{array}$ & IN3 & 0.938 & & & \\
\hline REL & $\begin{array}{l}\text { My religion asks me to find a } \\
\text { halal job } \\
\text { My religion determines my } \\
\text { future career } \\
\text { My religion asks me to be } \\
\text { self-reliant }\end{array}$ & $\begin{array}{l}\text { Abu Bakar et } \\
\text { al. (2016) } \\
\text { Abu Bakar et } \\
\text { al. (2016) } \\
\text { Abu Bakar et } \\
\text { al. (2016) }\end{array}$ & $\begin{array}{l}\text { REL2 } \\
\text { REL3 }\end{array}$ & $\begin{array}{l}0.758 \\
0.858 \\
0.818\end{array}$ & 0.660 & 0.853 & 0.741 \\
\hline PBC & $\begin{array}{l}\text { I have the ability to pursue } \\
\text { my future career as an } \\
\text { Islamic banker } \\
\text { I have the knowledge to } \\
\text { pursue my future career as } \\
\text { an Islamic banker } \\
\text { I have a control in selecting } \\
\text { my future career as an } \\
\text { Islamic banker }\end{array}$ & $\begin{array}{l}\text { Taylor and } \\
\text { Todd (1995) } \\
\text { Taylor and } \\
\text { Todd (1995) } \\
\text { Taylor and } \\
\text { Todd (1995) }\end{array}$ & $\begin{array}{l}\text { PBC1 } \\
\text { PBC2 }\end{array}$ & $\begin{array}{l}0.773 \\
0.904\end{array}$ & 0.719 & 0.884 & 0.801 \\
\hline SE & $\begin{array}{l}\text { Knowing enough to pursue } \\
\text { my future career as an } \\
\text { Islamic banker is important } \\
\text { to me } \\
\text { Being able to choose my } \\
\text { future career is important to } \\
\text { me } \\
\text { I know enough to choose my } \\
\text { future career }\end{array}$ & $\begin{array}{l}\text { Shih and Fang } \\
(2004) \\
\text { Shih and Fang } \\
\text { (2004) }\end{array}$ & $\begin{array}{l}\text { SE2 } \\
\text { SE3 }\end{array}$ & $\begin{array}{l}0.891 \\
0.946 \\
0.756\end{array}$ & 0.754 & 0.901 & 0.837 \\
\hline FC & $\begin{array}{l}\text { I have the time to think } \\
\text { about my future career as an } \\
\text { Islamic banker } \\
\text { I have the time needed to } \\
\text { pursue my future career as } \\
\text { an Islamic banker } \\
\text { I have the money needed to } \\
\text { invest in pursuing my future } \\
\text { career }\end{array}$ & $\begin{array}{l}\text { Shih and Fang } \\
\text { (2004) } \\
\text { Taylor and } \\
\text { Todd (1995) } \\
\text { Taylor and } \\
\text { Todd (1995) }\end{array}$ & FC1 & 0.889 & 0.747 & 0.898 & 0.837 \\
\hline WLS & $\begin{array}{l}\text { I plan to become an Islamic } \\
\text { banker in the future } \\
\text { My future career as an } \\
\text { Islamic banker is a priority } \\
\text { I will make every effort to } \\
\text { ensure I will become an } \\
\text { Islamic banker }\end{array}$ & $\begin{array}{l}\text { Shih and Fang } \\
\text { (2004) } \\
\text { Shih and Fang } \\
\text { (2004) } \\
\text { Shih and Fang } \\
\text { (2004) }\end{array}$ & $\begin{array}{l}\text { WLS1 } \\
\text { WLS2 }\end{array}$ & $\begin{array}{l}0.875 \\
0.855\end{array}$ & 0.732 & 0.891 & 0.818 \\
\hline
\end{tabular}

Notes: $C R=$ Composite Reliability, $C A=$ Cronbachs Alpha, ATT=Attitude, $C R=$ Career Reputation, $D N=$ Descriptive Norm, IN=Injunctive Norm, PBC=Perceived Behavioral Control, REL=Religion, $S E=S e l f$ Efficacy, $S N=$ Subjective Norm, WLS=Willingness, FL=Factor Loading. 
Amin | Predictors of Young People's Career Intentions as Islamic Bankers

Table 3. Discriminant Analysis

\begin{tabular}{lllllllllll}
\hline ITEM & ATT & CR & DN & FC & IN & PBC & REL & SE & SN & WLS \\
\hline ATT & 0.808 & & & & & & & & & \\
CR & 0.499 & 0.830 & & & & & & & & \\
DN & 0.358 & 0.383 & 0.837 & & & & & & & \\
FC & 0.271 & 0.257 & 0.314 & 0.864 & & & & & & \\
IN & 0.450 & 0.378 & 0.277 & 0.248 & 0.871 & & & & & \\
PBC & 0.279 & 0.326 & 0.414 & 0.526 & 0.274 & 0.848 & & & & \\
REL & 0.466 & 0.442 & 0.242 & 0.285 & 0.461 & 0.358 & 0.812 & & & \\
SE & 0.297 & 0.348 & 0.352 & 0.705 & 0.271 & 0.657 & 0.267 & 0.868 & & \\
SN & 0.433 & 0.470 & 0.320 & 0.325 & 0.641 & 0.363 & 0.240 & 0.410 & 0.864 & \\
WLS & 0.584 & 0.519 & 0.406 & 0.244 & 0.379 & 0.357 & 0.223 & 0.314 & 0.520 & 0.856 \\
\hline
\end{tabular}

Notes: ATT=Attitude, CR=Career Reputation, $D N=$ Descriptive Norm, IN=Injunctive Norm, $P B C=$ Perceived Behavioral Control, REL=Religion, SE=Self Efficacy, SN=Subjective Norm, $W L S=$ Willingness.

Besides factor analysis, we also examine the data obtained using AVE, composite reliability and Cronbach's alpha. The details are presented in Table 2. As for AVE, the results obtained indicate that all variables under contemplation were greater than the threshold value of 0.5 , meeting the convergent validity. As for $\mathrm{CR}$, the results also indicate that composite reliability for all constructs was beyond the recommended value of 0.70 , implying the convergent validity for the said constructs. Cronbach's alpha values for all variables were greater than the required value of 0.6, confirming acceptable internal consistency.

Moreover, a discriminant validity analysis is conducted to examine whether variables are distinct compared with others. Table 3 presents the square root of AVE for each variable was greater than the correlation with other constructs (bold values), meeting the test for discriminant validity. This means that each variable is different compared with other variables inferring the discriminant validity result is acceptable.

\subsection{Structural Model}

In evaluating the appropriateness of the pathways developed specifically in this study, PLS analyses were conducted by integrating all factors under contemplations. In this study, we hypothesized the willingness to pursue a career as Islamic bankers as the first dependent variable, whilst others like attitude, subjective norm and perceived behavioral control served not only as independent variables but also dependent variables for their decomposition. In more detail, attitude, subjective norm and perceived 
Amin | Predictors of Young People's Career Intentions as Islamic Bankers

behavioral control accounted for 44.44 per cent the variance of the willingness. The effects of attitude, subjective norm and perceived behavioral control on the willingness were statistically significant.

Table 4. Structural Analysis

\begin{tabular}{cccc}
\hline Pathway & Estimate (6) & t-value & Supported \\
\hline ATT $\rightarrow$ WLS & 0.421 & 8.039 & Yes \\
CR $\rightarrow$ ATT & 0.364 & 6.455 & Yes \\
DN $\rightarrow$ SN & 0.154 & 3.777 & Yes \\
FC $\rightarrow$ PBC & 0.126 & 2.182 & Yes \\
IN $\rightarrow$ SN & 0.598 & 14.843 & Yes \\
PBC $\rightarrow$ WLS & 0.134 & 2.793 & Yes \\
REL $\rightarrow$ ATT & 0.305 & 5.618 & Yes \\
SE $\rightarrow$ PBC & 0.568 & 10.703 & Yes \\
SN $\rightarrow$ WLS & 0.289 & 5.313 & Yes \\
\hline Notes: ATT=Attitude, CR=Career Reputation, DN=Descriptive Norm, IN=Injunctive Norm, \\
$P B C=$ Perceived Behavioral Control, REL=Religion, SE=Self Efficacy, SN=Subjective Norm, \\
WLS=WillingnesS.
\end{tabular}

The attitude was significantly related to the willingness ( $t=8.039, p$ value<0.000). Good attitude has a high likelihood to translate into the intention and willingness - and therefore potential future actual behavior is expected. This finding extends the generalizability of attitude to include the context of Islamic bankers, and thus extends the appropriateness of the theory as proven earlier Taylor and Todd (1995). Hence, the higher the extent of attitude, the better is the willingness. Similarly, we also discovered the significant effect of career reputation on the attitude $(t=6.455, p$ value $<0.000)$. This finding aligns with earlier studies extending the applicability of the career reputation in determining one's future career advancement (Turban et al., 1998; Ahmed et al., 1997; Felton et al., 1994). Furthermore, religiosity factor was also instrumental in determining attitude towards the willingness ( $t=5.618, p$-value $<0.000)$. This outcome is consistent with earlier works of Abu Bakar et al. (2016) and Wibowo (2017) in which religiosity level can determine individual's willingness to improve their work engagement and entrepreneurial intentions, respectively.

Moreover, the subjective norm was significantly related to the willingness $(t=5.313, p$-value $<0.000)$. Importantly, family influences are likely quite instrumental in determining one's job selection. This is proven correct when a study by Law (2010) confirmed a significant effect of parental influence on the decision to choose a CPA career. Typically, the goal congruence among family members can help establish one's career pathway. Our study also 
reported the significant effects of descriptive and injunctive norms on the subjective norm. Our findings were in light with Aronson et al. (2010) who claimed that injunctive norms are people perceptions of what behaviors are approved by others and descriptive norms are people perceptions of how people behave.

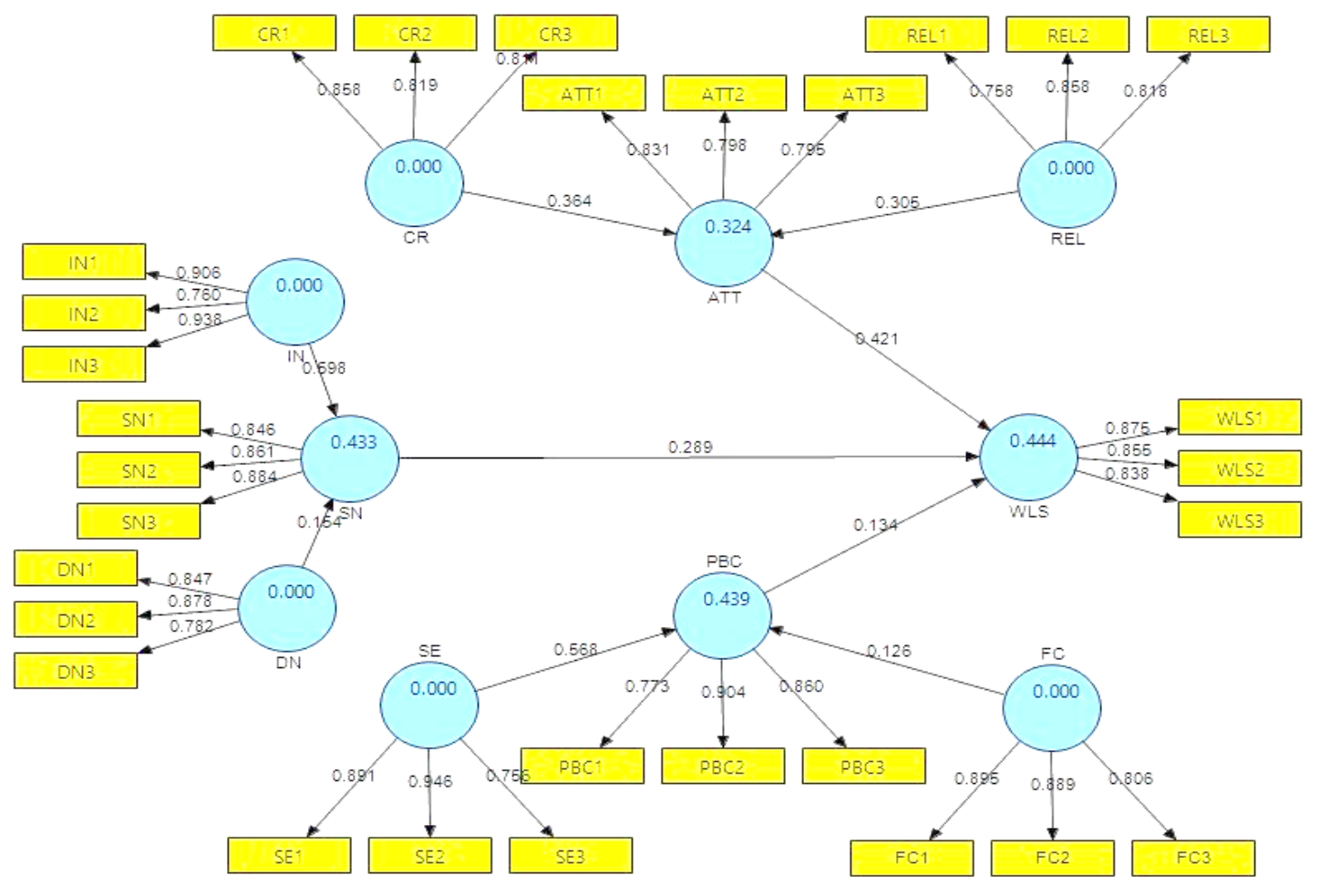

Figure 2. Analyzed Research Model

Perceived behavioral control was also a significant factor determining the willingness to pursue a career as Islamic bankers ( $t=2.793, p$-value $<0.000)$. This finding is related to one's ability, which indicates their skill, knowledge and importantly they have control over those materials at hand. Given this assertion, our finding provides another extension from the extant literature in which a work by Giles and Rea (1999) confirmed our hypothesis in that perceived behavioral control was essential for individuals to make a future career decision. Our finding also demonstrated the significant effect of selfefficacy on perceived behavioral control, confirming its alignment with Giles and Rea (1999). Since our study includes facilitating condition, the technical resources are rarely accessible to future bankers and because of that, the inclusion of the factor will offer another extension. Our study reported a significant relationship between facilitating condition and career option. The finding here is somewhat in tandem with a work of Teo et al. (2008), who asserted that facilitating conditions are environmental factors that influence 
Amin | Predictors of Young People's Career Intentions as Islamic Bankers

individuals' willingness to undertake certain types of tasks. In our cases, professional advice by existing bankers and exhibition about career pathways are two from many resources that can help students to make improved decision pertinent to their future career.

\subsection{Analysis}

This study has confirmed that all hypothesized relationships are proven to be significant and therefore the model developed is valid to represent young people's willingness to become future Islamic bankers. Of the factors considered, we found out that attitude ranked first and appeared to be critical, followed by people influence and control factor in understanding the reasons why young people choose Islamic bankers as their future job. The attitude of young people is shaped based on the respondents' perception of career reputation found in an Islamic banker job as well as the influence of religion. The information available about the job can determine young people's attitude in terms of good long-term earning, prospects and importantly high social prestige. On the other hand, the level of one's religion compliance can also determine his attitude towards future career pathway. This means that the willingness to take up the job is due to its halalness and importantly the earning of self-reliant among young people for their sustainability.

Studying career intentions among young graduates or even the final year students has been limited and falling short (Ahmed et al., 1997; Zain et al., 2010). Explaining in more detail, a study by Ahmed et al. (1997) examined about accounting students' career choice in New Zealand whilst Zain et al. (2010) examined about entrepreneurship intentions among Malaysian business students and jointly these studies have not paid any attention to why young people choose Islamic bankers as their future employment. This is perhaps owing to different research paradigm employed. In reality, however, our current study has been different compared with earlier works and the differences are found in several ways:

- $\quad$ First, the present study seeks to understand the factors determining young people's willingness to become Islamic bankers in the future using empirical investigations; and

- Second, the present study extends the applicability of the DTPB in understanding young people's willingness to choose the career pathway. Hence, the present study adds new knowledge about young people's willingness to become Islamic bankers where an examination of factors influencing is evaluated accordingly.

International Journal of Islamic Economics and Finance (IJIEF), 3(2), 143-170|160 
Amin | Predictors of Young People's Career Intentions as Islamic Bankers

In terms of contributions, this study has extended the DTPB, while retaining its parsimony within the context of Islamic banking employment. First, our adapted battery items are adjusted to reflect the present context. In the research model, the variables namely career reputation and religion are introduced to capture attitude towards the willingness whilst other variables are also captured based on literature analyses. Second, significant effects are found to all proposed hypothesized relationships that proved our proposed theoretical framework for Islamic banker is valid and appropriate. Third, this study supports Taylor and Todd's (1995) research that found significant relationships between subjective norm, descriptive and injunctive norms, and therefore extend their generalisability to Islamic banking employment setting. It also extends the contributions made by various studies earlier, which are extending the DTPB and found it valid to obtain extensions and so do the present case (Md Husin \& Ab Rahman, 2016; Shih \& Fang, 2004). Importantly, we modify battery items identified from previous pieces of literature to echo the current context, where specific instruments are developed that become as a guide for future researchers, where Islamic banking employment comes into play.

\section{Research Implications}

\subsection{Theoretical Implications}

In this study, we decomposed attitude into religiosity and career reputation, the subjective norm decomposed into injunctive and descriptive norms and perceived behavioral control decomposed into self-efficacy and facilitating condition. The proposed model efficaciously applied the extended DTPB to career intentions as Islamic bankers to strengthen our belief of Islamic finance students' willingness to put themselves as our future Islamic bankers. It is worth noting that ignoring the students' perception of career intentions as Islamic bankers may lead to career intentions' model that is sketchy and conceivably misleading. Acknowledging the DTPB as a baseline theory, this study focused on the career intentions as Islamic bankers to concede how to develop an effective job outlet for future bankers, where the supports are not only from public universities but also visioned by Islamic banks. Besides, this study makes a key contribution by explaining the students' behavioral intention in the Islamic banking context. Our study, furthermore, extended the usefulness of the DTPB to include Islamic bankers as an essential career pathway among the student, and therefore new extensions and generalizations are drawn from the current study.

International Journal of Islamic Economics and Finance (IJIEF), 3(2), 143-170|161 
Amin | Predictors of Young People's Career Intentions as Islamic Bankers

\subsection{Methodological Implications}

This study offers two methodological implications. First, we enhance the battery items used in this study, identified through literature analyses and later received refinement through the pilot test, which was identified the ambiguity and later adjustment made to ensure the battery items employed can be easily understood plainly by respondents of interest. Second, the cross-discipline battery items' application is acceptable. Our battery items were identified from other areas, not related directly to career intentions as Islamic bankers. After adjustments, they were valid and reliability proven in our empirical analyses. Hence, this approach indicated that borrowing or extending measures from other disciplines are acceptable provided reconciliation is taken place to reflect the context under contemplation. Third, our use of PLS is somewhat splendid and efficient given the running of data for analyses can be done simultaneously and subsequently adjustments to delete the invalid item, if any, can easily be done through the graphical adjustments found in the PLS analysis. Our study revealed a message in that PLS is accepted to be applied to a new case like in the case of career intentions as Islamic bankers.

\subsection{Practical Implications}

Consistent with the DTPB, our results obtained indicated that the students' willingness to take up Islamic bankers as their future job is collectively explained by their attitude, subjective norm and perceived behavioral control. Of the attitudinal beliefs, their religiosity and career reputation determine their attitude. Hence, providing career knowledge about Islamic bankers, sufficient learning about the job and its description might contribute to inculcate a positive attitude of the students towards their willingness to be future Islamic bankers. As for injunctive and descriptive norms, there is a need to tap into social media markets through the creation of groups of people who share a concern or a passion about being Islamic bankers (i.e. Facebook and Instagram). Importantly, there is also a need into developing the concept word-of-mouth online that can facilitate the formation of individuals' decision to become Islamic bankers. Besides, family, friends and peers who existed both online and offline can promote a positive image about becoming Islamic bankers would have a greater effect than mass media reports. Another important practical finding was that students with high self-efficacy have greater perceived behavioral control compared with their peers. Hence, improving their control perceptions of career intentions as Islamic bankers can enhance their willingness. Besides, facilitating condition can also serve as a contributing factor determining the students' willingness. Enhanced training courses through industrial training

International Journal of Islamic Economics and Finance (IJIEF), 3(2), 143-170|162 
Amin | Predictors of Young People's Career Intentions as Islamic Bankers

provided by Islamic banks to the students should be made accessible to everyone.

\section{Conclusion and Recommendation}

\subsection{Conclusion}

This work aimed to examine some factors that might influence the decisions of the students to choose Islamic bankers as their future job in the Malaysian banking industry. The results obtained suggest that the students who intend to select a career as Islamic bankers give significantly higher priority to attitude, followed by the subjective norm and perceived behavioral control. Attitude is an intrinsic factor and is shaped through one's interaction with others on future career and the disseminated career information, in which these are processed greatly before one is ended up with a final career decision. Similarly, not surprisingly, they perceive the benefits of becoming Islamic bankers to be greater than religiosity, and these two factors were significantly determined attitude towards career intentions as Islamic bankers. Career reputation that includes a good salary, benefit and whatsoever are some of the reasons behind the significant outcome. Further, the results obtained indicate that the injunctive norm was more influential than the descriptive norm in explaining subjective norm. Existing exhibitions and shared careers' success by extant Islamic bankers are some leading attributes to this manageable result - implying others' approval is appealing. The results also indicate that self-efficacy is more likely determining career intentions compared with its peer - facilitating condition. This suggests that one can determine the best in his selection of future career.

\subsection{Recommendation}

The results obtained provide an essential guide for practitioners in promoting Islamic banker as a future job among final year students at universities. As such, managers of Islamic banks should hire graduates based on their merits and the success of the interview process at the expense of double standard conception. The findings obtained also suggest managers should make resources available in terms of the information center, specialized personnel and materials of future employment to support young people's willingness to become Islamic bankers. For regulators, the results obtained in this study suggest that the government can stimulate young people's participation in the industry by improving the information available about future jobs in the Islamic banking industry, financial incentives and importantly provide finishing course before they can enter the job market.

$$
\text { International Journal of Islamic Economics and Finance (IJIEF), 3(2), 143-170| } 163
$$


Amin | Predictors of Young People’s Career Intentions as Islamic Bankers

Offering final year students with cogent courses required specifically for the industry is relatively essential. By itself, a collaboration between the government, practitioners and universities are vital to produce synergy in attracting young graduates to participate in the industry, which in turn, can strengthen its talent management.

Likewise, the results of the study should be interpreted in light of several limitations. First, the use of third-year students as proxies for actual graduates may have reduced external validity. Future research should focus on actual graduates seeking employment in Malaysia. Second, the study was examining the career intentions as Islamic bankers of the students of Islamic finance program and the perception drawn from other business and finance students were not elicited. Future research is therefore expected to include them to investigate their career intentions and the question of whether the factors impacting Islamic finance students will be similar to these students will be answered.

Despite these limitations, our study served as an eye-opener to all Islamic finance scientists to explore further this discipline of research for extensions and generalizations, at least.

\section{Acknowledgement}

I would like to thank my family members for their encouragement. My father, $\mathrm{Hj}$ Amin Hassim who taught me the meaning of hardworking and dedication. My mother, Hjh Halima Undang, who made his life better. My wife, Zuraidah Anis for her extraordinary support in this article publication process. My children, Muhammad Nour Imran (Otto), Nasrullah (Chul), Nasrudin (Addin) and Nasrulhaq (Haq) - May Allah SWT grant them success now and always, Ameen. 
Amin | Predictors of Young People's Career Intentions as Islamic Bankers

\section{References}

Abu Bakar, R., Cooke, F. L., \& Muenjohn, N. (2016). Religiosity as a source of influence on work engagement: A study of the Malaysian Finance industry. The International Journal of Human Resource Management, 29(18), 2632-2658.

Ahmed, K., Alam K.F., \& Alam, M. (1997). An empirical study of factors affecting accounting students' career choice in New Zealand. Accounting Education, 6(4), 325-335.

Ajzen, I. (1991). The theory of planned behaviour. Organizational Behavior and Human Decision Processes, 50, 179-211.

Ajzen, I. (2002). Perceived behavioural control, self-efficacy, locus of control, and the theory of planned behaviour. Journal of Applied Social Psychology, 32, 665-683.

Aronson, E., T.D. Wilson., \& R.M. Akert. (2010). Social psychology. Upper Saddle River, NJ: Prentice-Hall.

Ayodele, T. O. (2019). The career choice of real estate students in Nigeria The explaining influences in comparative perspective. Property Management, 37(1), 154-176.

Bandura, A. (1986). Social foundations of thought and action: A social cognitive theory. Englewood Cliffs, NJ: Prentice-Hall.

Bank Negara Malaysia (2011). Financial sector blueprint 2011-2020. Kuala Lumpur: Bank Negara.

Cialdini, R. B. (2007). Influence: The Psychology of Persuasion. New York: HarperCollins.

Felton, S., Burh, N., \& Northey, M. (1994). Factors influencing the business student's choice of a career in chartered accountancy. Issues in Accounting Education, 9(1), 131-141.

Giles, M., \& Rea, A. (1999). Career self-efficacy: An application of the theory of planned behaviour. Journal of Occupational and Organisational Psychology, 72, 393-398.

Hair Jr, J. F., Hult, G. T. M., Ringle, C., \& Sarstedt, M. (2016). A primer on partial least squares structural equation modelling (PLS-SEM). Sage publications.

ICD Thomson Reuters(2019). Islamic finance development indicator (IFDI). Thomson Reuters.

Khapova, S. N., Arthur, M. B., Wilderom, C. P., \& Svensson, J. S. (2007). Professional identity as the key to career change intention. Career Development International, 12(7), 584-595. 
Amin | Predictors of Young People's Career Intentions as Islamic Bankers

Law, P. K. (2010). A theory of reasoned action model of accounting students' career choice in public accounting practices in the post-Enron. Journal of Applied Accounting Research, 11(1), 58-73.

Lawson E.E. (2016). The effects of injunctive and descriptive normative influence on stigmatizing attitudes toward individuals with mental illness (Doctoral Thesis). Georgia Southern University.

Lee, Y., \& Kozar, K.A. (2008). An empirical investigation of anti-spyware software adoption: A multi-theoretical perspective. Information and Management, 45(2), 109-119.

Lin, H. F. (2010). Applicability of the extended theory of planned behaviour in predicting job seeker intentions to use job search websites. International Journal of Selection and Assessment, 18(1), 64-74.

Mathieson, K. ( 1991 ). Predicting user intention: Comparing the technology acceptance model with the theory of planned behaviour. Information Systems Research, 2(3), 173-191.

Md Husin, M., \& Ab Rahman, A. (2016). Predicting intention to participate in family takaful scheme using the decomposed theory of planned behaviour. International Journal of Social Economics, 43(12), 1351-1366.

Rana, N. P., Dwivedi, Y. K., Lal, B., \& Williams, M. D. (2015). Assessing citizens' adoption of a transactional e-government system: Validation of the extended decomposed theory of planned behaviour (DTPB). (2015). PACIS 2015 Proceedings. 217.

Reinartz, W., Haenlein, M., \& Henseler, J. (2009). An empirical comparision of the efficacy of covariance-based and variance-based SEM. International Journal of Research in Marketing, 26, 332-344.

Ringle, C. M, Wende, S., \& Will, A. (2005). SmartPLS2.0 M3. PLS.

Shih, Y. Y., \& Fang, K. (2004). The use of a decomposed theory of planned behaviour to study Internet banking in Taiwan. Internet Research, 14(3), 213-223.

Smith, J. R., \& Louis, W. R. (2008). Do as we say and as we do: The interplay of descriptive and injunctive group norms in the attitude-behaviour relationship. British Journal of Social Psychology, 47, 647-666.

Sugahara, S., \& Boland, G. (2006). Perceptions of the certified public accountants by accounting and non-accounting tertiary students in Japan. Asian Review of Accounting, 14 Nos. 1/2, 149-167.

Taylor, S., \& Todd, P. (1995). Decomposition and crossover effects in the theory of planned behaviour: A study of consumer adoption intentions. International Journal of Research in Marketing, 12(2), 137-155. 
Amin | Predictors of Young People's Career Intentions as Islamic Bankers

Teo, T., C. B. Lee., \& C. S. Chai. (2008). Understanding preservice teachers' computer attitudes: Applying and extending the Technology Acceptance Model. Journal of Computer Assisted Learning. 24(2), 128-143.

Turban, D. B., Forret, M. L., \& Hendrickson, C. L. (1998). Applicant attraction to firms: Influences of organization reputation, job and organizational attributes, and recruiter behaviours. Journal of Vocational Behavior, 52(1), 24-44.

Van Hooft, E. A., \& De Jong, M. (2009). Predicting job-seeking temporary employment using the theory of planned behaviour: The moderating role of individualism and collectivism. Journal of Occupational and Organizational Psychology, 82(2), 295-316.

Wibowo, B. (2017). Religiosity and entrepreneurial intention. Etikonomi, 16(2), 187-206.

Zain, Z. M., Akram, A. M., \& Ghani, E. K. (2010). Entrepreneurship intention among Malaysian business students. Canadian Social Science, 6(3), 3444.

Zolait, A. H. S. (2010). An examination of the factors influencing Yemeni Bank users' behavioural intention to use Internet banking services. Journal of Financial Services Marketing, 15(1), 76-94. 


\section{Appendix A. Research Questionnaire Battery Items}

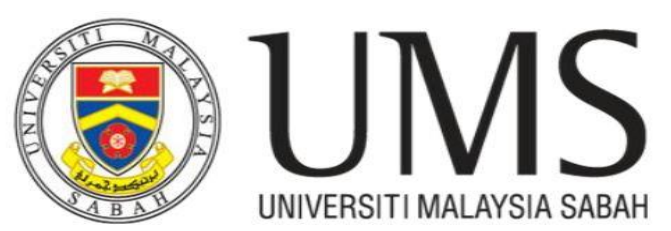

Dear respected respondent,

We invite you to participate in this questionnaire survey, which is on young people's willingness to become Islamic bankers.

Thank you for your willingness to spare your time in answering this questionnaire. We request that you read the instructions provided carefully and to respond as accurately as possible. You are the respondent of this study if you meet the following criteria:

1. You are well-exposed to Islamic finance both formally and informally

2. You wish to become an Islamic banker in the future

All information provided is confidential and will be used for research analysis purposes only.

If you have any doubts, questions or in need of clarification, please do not hesitate to contact me. Your kind cooperation in this study is highly appreciated. Thank you.

Yours sincerely,

Hanudin Amin, PhD

Researcher

(C) Hanudin Amin, PhD 
Amin | Predictors of Young People’s Career Intentions as Islamic Bankers

\section{SECTION A: FACTORS INFLUENCING}

Listed below are a series of statements about the FACTORS for PREFERENCE TO BECOME AN ISLAMIC BANKER. Please indicate the degree of your agreement or disagreement with each statement by circling only ONE of the five alternatives after each statement.

\begin{tabular}{|c|c|c|c|c|}
\hline ABSOLUTELY DISAGREE & DISAGREE & SLIGHTLY DISAGREE & AGREE & ABSOLUTELY AGREE \\
\hline 1 & 2 & 3 & 4 & 5 \\
\hline
\end{tabular}

Attitude

\begin{tabular}{|l|l|l|l|l|l|l|}
\hline ATT & Becoming an Islamic banker is a good idea & 1 & 2 & 3 & 4 & 5 \\
\hline & Becoming an Islamic banker is something positive & 1 & 2 & 3 & 4 & 5 \\
\hline & Becoming an Islamic banker is beneficial & 1 & 2 & 3 & 4 & 5 \\
\hline
\end{tabular}

Career reputation

\begin{tabular}{|l|l|l|l|l|l|l|}
\hline CR & Pursuing a career as an Islamic banker has a good long term earning & 1 & 2 & 3 & 4 & 5 \\
\hline & Being as a future Islamic banker has excellent prospects & 1 & 2 & 3 & 4 & 5 \\
\hline & Being as a future Islamic banker has high social prestige & 1 & 2 & 3 & 4 & 5 \\
\hline
\end{tabular}

Religion

\begin{tabular}{|l|l|l|l|l|l|l|}
\hline REL & My religion asks me to find a halal job & 1 & 2 & 3 & 4 & 5 \\
\hline & My religion determines my future career & 1 & 2 & 3 & 4 & 5 \\
\hline & My religion asks me to be self-reliant & 1 & 2 & 3 & 4 & 5 \\
\hline
\end{tabular}

\section{Subjective norm}

\begin{tabular}{|c|c|c|c|c|c|c|}
\hline SN & $\begin{array}{l}\text { The people who influence my decisions would think that I should } \\
\text { pursue my future career as an Islamic banker }\end{array}$ & 1 & 2 & 3 & 4 & 5 \\
\hline & $\begin{array}{l}\text { The people who influence my decisions would think that I should } \\
\text { consider my future career as an Islamic banker }\end{array}$ & 1 & 2 & 3 & 4 & 5 \\
\hline & $\begin{array}{l}\text { The people who influence my decisions would think that I should } \\
\text { define my future career as an Islamic banker }\end{array}$ & 1 & 2 & 3 & 4 & 5 \\
\hline
\end{tabular}

Descriptive norm

\begin{tabular}{|l|l|l|l|l|l|l|}
\hline DN & My friends will pursue their future career as Islamic bankers & 1 & 2 & 3 & 4 & 5 \\
\hline & My siblings will pursue their future career as Islamic bankers & 1 & 2 & 3 & 4 & 5 \\
\hline $\begin{array}{l}\text { Most people who are significant to me will pursue their future career } \\
\text { as Islamic bankers }\end{array}$ & 1 & 2 & 3 & 4 & 5 \\
\hline
\end{tabular}

Injunctive norm

\begin{tabular}{|c|c|c|c|c|c|c|}
\hline IN & $\begin{array}{l}\text { My parents will think I should pursue my future career as an Islamic } \\
\text { banker }\end{array}$ & 1 & 2 & 3 & 4 & 5 \\
\hline & $\begin{array}{l}\text { My siblings will think I should pursue my future career as an Islamic } \\
\text { banker }\end{array}$ & 1 & 2 & 3 & 4 & 5 \\
\hline & $\begin{array}{l}\text { My friends will think I should pursue my future career as an Islamic } \\
\text { banker }\end{array}$ & 1 & 2 & 3 & 4 & 5 \\
\hline
\end{tabular}


Amin | Predictors of Young People's Career Intentions as Islamic Bankers

\section{Perceived behavioral control}

\begin{tabular}{|l|l|l|l|l|l|l|}
\hline PBC & I have the ability to pursue my future career as an Islamic banker & 1 & 2 & 3 & 4 & 5 \\
\hline $\begin{array}{l}\text { I have the knowledge to pursue my future career as an Islamic } \\
\text { banker }\end{array}$ & 1 & 2 & 3 & 4 & 5 \\
\hline & I have a control in selecting my future career as an Islamic banker & 1 & 2 & 3 & 4 & 5 \\
\hline
\end{tabular}

Self-efficacy

\begin{tabular}{|c|c|c|c|c|c|c|}
\hline SE & $\begin{array}{l}\text { Knowing enough to pursue my future career as an Islamic banker is } \\
\text { important to me }\end{array}$ & 1 & 2 & 3 & 4 & 5 \\
\hline & Being able to choose my future career is important to me & 1 & 2 & 3 & 4 & 5 \\
\hline & I know enough to choose my future career & 1 & 2 & 3 & 4 & 5 \\
\hline
\end{tabular}

Facilitating condition

\begin{tabular}{|l|l|l|l|l|l|l|}
\hline FC & I have the time to think about my future career as an Islamic banker & 1 & 2 & 3 & 4 & 5 \\
\hline & $\begin{array}{l}\text { I have the time needed to pursue my future career as an Islamic } \\
\text { banker }\end{array}$ & 1 & 2 & 3 & 4 & 5 \\
\hline & I have the money needed to invest in pursuing my future career & 1 & 2 & 3 & 4 & 5 \\
\hline
\end{tabular}

\section{Willingness}

\begin{tabular}{|l|l|l|l|l|l|l|}
\hline WLS & I plan to become an Islamic banker in the future & 1 & 2 & 3 & 4 & 5 \\
\hline & My future career as an Islamic banker is a priority & 1 & 2 & 3 & 4 & 5 \\
\hline & I will make every effort to ensure I will become an Islamic banker & 1 & 2 & 3 & 4 & 5 \\
\hline
\end{tabular}

\section{SECTION B: DEMOGRAPHIC}

Listed below are items about the DEMOGRAPHIC OF RESPONDENT for CAREER INTENTIONS AS ISLAMIC BANKERS. Please CIRCLE only ONE of the alternatives available.
1. Gender
a. Female
b. Male
2. Age
a. $<20$
b. $21-30$
c. $>31$
3. Ethnic
a. Malay
b. Aboriginal Sabahan
c. Aboriginal Sarawakian

(C) Hanudin Amin, PhD 